\title{
Synergy of Prosecutors, Police and Corruption Eradiction Commision to Handle Corruption in the Frame of Integrated Criminal Justice System
}

\author{
Titin Herawati Utara ${ }^{1}$, Supanto ${ }^{2}$, Yudho Taruno Muryanto ${ }^{3}$ \\ ${ }^{1.2 .3}$ Universitas Sebelas Maret \\ Surakarta, Indonesia \\ utara_76@yahoo.com
}

\begin{abstract}
The results show that efforts to recover assets are a difficult process, even under ideal circumstances, asset recovery efforts are complex and multidisciplinary processes, including differences in legal systems; banking secrecy system; unwillingness of developed countries to assist in asset recovery efforts; and weak political will. The synergy of the Prosecutor's Office, the National To improve the optimization of the handling of corruption eradication, an agreement was made between the Police, the KPK and the Attorney General's Office Article 8 paragraph (1) expressly regulates in the event that the parties carry out an investigation on the same target to avoid duplication of the investigation, Next, the agency makes an order to carry out an investigation. Article 8 paragraph (4) expressly regulates and the one of the parties can carry out an investigation of a criminal act of corruption, can be transferred to another party in accordance with statutory provisions by first carrying out the case title attended by the parties whose implementation is outlined in the official report. Article 9 paragraph (1) expressly regulates: Supervision can be carried out jointly against corruption crime problem that get the attention / concerns of the community and / or the attention of the parties.
\end{abstract}

Keywords - corruption, integrated criminal justice system.

\section{INTRODUCTION}

Eradicating corruption is not an easy job. The eradication of corruption must be handled seriously. The development Criminal Justice System in Indonesia began with the enactment of Number. 8 of 1981 about Criminal Procedure Code (KUHAP) as a substitute for the criminal procedure law for the Dutch colonial heritage, namely Het Herziene Inlandsch Reglement [1]. The enactment of the Criminal Procedure Code changes from colonial justice system to Indonesian Criminal Justice System at the same time. These changes have fundamental and widespread implications in the form of fundamental changes both conceptually and in implementation of procedures for the resolution of criminal cases in Indonesia [2].

The Criminal Justice System is also understood as a mechanism of action in combating crime with the use of a basic system. This mechanism is basically the result of interaction between laws and regulations, criminal justice administration practices, social attitudes, and a rational system, all of which give certain results with all its limitations. In addition, Crime control system in Criminal
Justice System consist of the Police, Attorney General, General Courts and Penitentiary institutions.

The National Police as part of the Indonesian Criminal Justice System has a very important role in criminal law enforcement. One of the functions of National police is to protect and community service. Police are authorized to conduct criminal investigations that were preceded by an investigation. This authority also covers the investigation of corruption.

Apart from the police, the prosecutor's office also conducts investigations and law enforcement on corruption. In addition to the police, the prosecutor's office also conducts investigations and law enforcement on corruption crimes [3]. In 2019 the Prosecutor's Office returned Rp. 20.5 trillion in state funds and US\$ 263.9 thousand, this shows that the prosecutor's office is able to recover state losses of $\mathrm{Rp} .49 .2$ billion in the state treasury. In 2019, the Corruption Eradication Commission in total carried out 96 investigations, 99 investigations, and 77 prosecution activities, for both new and old cases. The KPK succeeded in executing 81 court decisions and depositing 497.6 billion rupiah in the state treasury. The handling of corruption carried out by the National Police and the KPK is an extraordinary handler.

Corruption (TPK) is not only a legal problem but has become an economic, cultural and political problem. The increase in criminal acts of corruption has brought disasters not only to the life of the nation and state in general, but also can cause various weaknesses in the lives of future generations. The failure of law enforcement can be rooted in the non-operation of the system or obstruction of one component of the criminal justice system in carrying out its role, starting from the investigation, prosecution, examination in court and in the implementation of his own criminal case. For this reason, strict, consistent and non-discriminatory law enforcement is needed for corruptors. To realize the pillars of justice and legal certainty, consistent and nondiscriminatory law enforcement is very important. Its can bring benefits to the community in the form of a deterrent effect, so as to in law enforcement efforts and strengthened support law enforcement agencies very important to prevent someone who wants to commit corruption and the growth of public trust [4]. Research question in this paper is, What is the form of synergy 
between the prosecutor's office, the police and the commission to handle corruption in the frame of the integrated criminal justice system.

\section{RESEARCH METHOD}

This type of research uses the normative legal research method, which is a scientific research procedure to find the truth based on legal scientific logic from the normative side [5]. In this normative law research is more focused on examining the application of the rules or norms in positive law, especially those relating to the form of synergy between the prosecutor's office, the police and the commission to handle corruption in the frame of the integrated criminal justice [6]. In normative legal research or library data collection techniques used are literature studies of legal materials and non-legal materials [7].

The laws and regulations that are the primary material in this research include, among others, the criminal procedure law, the Law on the Prosecutor's Office Number 16 of 2004, concerning the Police Law Number 2 of 2022 and the KPK Law Number 30 of 2002. In addition to journals and books used as secondary legal materials, this research also uses legal dictionaries, and court decisions about the synergy between the Police, the KPK and the Prosecutor's Office.

This research is a descriptive study because it aims to provide an overview of community behavior as well as collaboration between the prosecutor's office, the police, and the KPK in handling corruption. In this study using deductive analysis techniques as the basis for drawing conclusions. The data analysis technique used in this research is the deductive analysis method, namely the data analysis method that begins with general postulates and certain paradigms as the basis for starting conclusions.

\section{FINDINGS AND DISCUSSION}

The definition of the rule of law according to Aristotle has the meaning that the state is a policy, therefore, as a state of law, the actions and activities carried out by the state must be based on law. Aristotle formulated a rule of law is a state that stands on the law that guarantees justice to its citizens [8]. There are 3 (three) principles by AV Dicey that must be implemented: (1) The rule of law (supremacy); (2) Equality before the law, and (3) Human rights. Process of law enforcement, there are several factors that influence the success of its implementation [9].

Referring to the factors above to existence of laws and regulations, The law enforcement institution and its implementation through a working mechanism in a Criminal Justice System is needed. In the perspective of the criminal justice system, law enforcement covers all powers by investigating bodies / institutions, the power of prosecution by public prosecuting bodies / institutions, the power of judging by judicial institutions, and the power of implementing a decision / criminal by a prison body / institution.

The expected integration in the criminal justice system for handling corruption crimes is carried out starting from the investigation, prosecution and examination in court trials, reading of decisions, legal services and the implementation of judges' decisions that have legal power will be carried out in an integrated and integrated manner by the parties included integrated criminal justice sub system, among others, namely:

a) The Indonesia Police

Law Number 2 Article 14 letter g 2002 about National Police

"The National Police of the Republic of Indonesia is tasked with: Conducting investigation and investigation of all criminal acts in accordance with criminal procedure code and other laws and regulations"

b) Prosecutors' Office

In criminal field, the prosecutor's office has the duty and authority to investigate certain criminal acts based on the law

c) Corruption Eradication Commission

In Law Number 30 of 2002 concerning the KPK, it is explained in Articles 6 and 7 that the KPK is tasked with coordinating the eradication of corruption with the competent authorities. The agency authorized to handle Corruption will be supervised by the KPK, carry out the investigation, investigation and prosecution process and supervise the government.

In the Article 7 coordination referred to in Article 6 letter a, the KPK has the authority, among others:

a. coordinate with relevant agencies regarding the investigation and prosecution of corruption cases

b. make a systematic reporting in cases of criminal acts of corruption

c. ask other agencies to report on corruption eradication activities carried out

d. ask other agencies to report on corruption prevention activities that have been carried out

In addition to the aforementioned provisions, there are also provisions that The prosecutor's office, the police and the KPK have an agreement that contains:, work mechanisms between the three agencies so that in handling criminal acts of corruption can run well and there is no conflict of authority, duplication in handling. Provisions governing the cooperative relationship between the Republic of Indonesia Attorney General's Office, Police and KPK include:

a. Joint Regulations of Indonesia Police and Attorney General's Office No. Pol: 2 of 2006

Number: KEP-019 / A / JA / 03/2006 concerning optimization of coordination in the eradication of the Corruption Act on March 7, 2006

b. Agreement between the Prosecutor's Office, Indonesia Police and KPK

Number: KEP-049 / A / J / A.3 / 2012

Number: B / 23 / III / 2012

Number: SPI-39/01/03/2012. 
Agreement between the Prosecutor's Office, Indonesia Police Officer and the Corruption Eradication Commission regarding the Optimization of the Eradication of Coordination of Funds: Article 8 paragraph (1) expressly regulates in the event that the parties carry out an investigation on the same target The importance of the determination made by the agency that is obliged to carry out the investigation, this is done to avoid duplication of the investigation. Article 8 paragraph (4) expressly regulates, the investigation and investigation of each party to agaist criminal, can be do by another party with consideration as statutory provisions by first carrying out the case title attended by the parties whose implementation is outlined in the official report

Article 9 paragraph (1) expressly regulates: Supervision can be carried out jointly against concern of the community and / or the attention of the parties. Concerns over overlapping authority or the struggle for "land" Article 11 of the Corruption Crime Law explains the integration in investigations and prosecutions carried out by the prosecutor's office, the police and the KPK. Article 11 explicitly states that the Corruption Eradication Commission has the authority to investigate, investigate and prosecute corruption if [10], Law enforcement officials, state administrators and other parties involved will be followed up by law enforcement officers get a lot of attention from the public harm the country at least 1 billion rupiah.

\section{CONCLUSION}

Criminal Justice System that integrated is become important because it is an instrument in the framework of enforcing material criminal law which aims to achieve the optimization of criminal law enforcement. Specifically, for handling corruption cases, in addition to the prosecutors and the police, a special commission government was also formed which also handles corruption, namely the Corruption Eradication Commission (KPK) based on Law Number 30 of 2002. Based on the above explanation, it can be seen that the agreement between the prosecutor, the police and the KPK in handling corruption can run well and be maximal without causing noise in the community in the context of law enforcement in the field of corruption.

\section{REFERENCES}

[1] Oentoeng Wahjoe, 2011. Hukum Pidana Internasional, Perkembangan tindak pidana internasional dan proses penegakannya, penerbit erlangga, Jakarta

[2] Barda Nawawi Arief, 2007. Kapita Selekta hukum pidana tentang system peradilan [3] pidana terpadu, BP Undip, semarang

[3] Faisal Santiago. 2017. "Penegakan Hukum Tindak Pidana Korupsi oleh Penegak Hukum untuk Terciptanyan Ketertiban Hukum", Pagaruyuang Law Journal, Volume 1 No 1

[4] Bambang Waluyo. 2017. "Upaya Taktis dan Strategis Pemberantasan Korupsi di Indonesia”, Lex Publica,, Jurnal Ilmu Hukum Asosiasi Pimpinan Perguruan
Tinggi Hukum Indonesia, Volume IV, Nomor 1, hlm. 627-628

[5] Johnny Ibrahim, 2006," Teori dan Metodologi Penelitian Hukum Normatif", PT. Remaja Rosdakarya Bandung.

[6] Dewanta, Mukti Fajar dan Yulianto Achmad, 2013, Dualisme Penelitian Hukum Normatif dan Empiris, Yogyakarta:Pustaka Pelajar.

[7] Dewanta, Mukti Fajar dan Yulianto Achmad, 2013, Dualisme Penelitian Hukum Normatif dan Empiris, Yogyakarta:Pustaka Pelajar.

[8] Kusnardi dan Harmaily Ibrahim, 1985. Hukum Tata Negara Indonesia, pusat studi HTN FH UI, Sinar Bakti, Jakarta

[9] Soerjono Soekanto, 2013. "Faktor-faktor yang mempengaruhi penegakan hukum", Raja Grafindo persada, Jakarta

[10] IGM. Nurdjana, 2009. Sistem Hukum Pidana dan Bahaya Laten Korupsi Problematika Sistem Hukum Pidana dan Implikasinya pada Penegakan Hukum Tindak Pidana Korupsi, Yogyakarta, Total Media 